\title{
Carbon Taxation and Policy Labeling: Experience from American States and Canadian Provinces
}

\author{
Barry G. Rabe \\ University of Michigan \\ Christopher P. Borick \\ Muhlenberg College
}

\begin{abstract}
A vast economics literature embraces taxation of the carbon content of fossil fuels as the superior policy approach for reducing greenhouse gas emissions. However, experience around the world suggests that carbon taxes face exceedingly difficult political hurdles. Federal experience in the United States and in Canada confirms this pattern. This article reviews sub-federal policy development among American states and Canadian provinces, a great many of which have pursued climate policy development. With one major exception, explicit carbon taxation appears to remain a political nonstarter. At the same time, states and provinces have been placing indirect carbon prices on fossil fuel use through a wide range of policies. These tend to strategically alter labeling, avoiding the terms of "tax" and "carbon" in imposing costs. The article offers a framework for considering such strategies and examines common design features, including direct linkage between cost imposition and fund usage to build political support.
\end{abstract}

KEY WORDS: Canada, United States, North America, energy taxation, carbon taxation, climate change, climate policy, state and provincial environmental policy

olicy ideas generated by the discipline of economics often face great difficulty when efforts are made to translate them into actual policy through political institutions. "In a democracy, economic policy is set not by economists but by the general public," laments Harvard economist Gregory Mankiw, a former senior economic advisor to President George W. Bush. Indeed, that "general public" may prefer policies that run counter to economic conventional wisdom, even when a broad consensus exists that unites ideologically diverse economic analysts. Hence, sustained fiscal deficits may concern many economists but appeal to the general citizenry and their representatives, offering demonstrable short-term benefits (higher services and lower taxes) while deferring costs to later generations. In turn, efforts to create "fairer" and "more effective" systems of taxation, such as swapping lower marginal rates for elimination of particular credits and exemptions, often face enormous resistance when proposed for political consideration.

Perhaps no idea in the arena of energy and climate policy has so unified diverse economists as the use of explicit carbon pricing through taxation. This approach offers the possibility of deterring fossil fuel use by taxing the level of carbon dioxide released by combustion of such fuels as coal, petroleum, and natural gas (Graetz, 2011). An ever-growing band of economists around the world has embraced this approach, noting its ability to clearly and directly deter fossil fuel consumption. Such taxes are easily within the constitutional bounds of most national and subnational governments around the world and would be technically and administratively straightforward to administer. They could be set at levels designed to achieve various

Review of Policy Research, Volume 29, Number 3 (2012) 10.1111/j.1541-1338.2012.00564.x (C) 2012 by The Policy Studies Organization. All rights reserved. 
policy goals such as reduced emissions of greenhouse gases and conventional air contaminants as well as dependence on imported energy sources. Their establishment could be linked with commensurate reductions of other taxes or elimination of less cost-effective regulations and tax subsidies. It is difficult to understate the extent to which this carbon taxation idea has demonstrated enormous appeal among academic, think tank, and journalistic economists in the policy arena of climate change. Indeed, there is precedent for using consumption taxes to drive policy change in other areas, such as the central role of increased cigarette excise taxes to deter smoking in recent decades.

This broad body of support has led to no shortage of proposals to make some version of carbon taxes a centerpiece in energy and climate policy in nations around the globe, although the political track record for these is none too strong. In 2010 and 2011, major carbon tax initiatives were advanced in Australia, France, and India, albeit with enormous political resistance. This pattern has also been evident at the federal level in Canada and in the United States, where periodic proposals for some form of carbon taxation have faced routine rejection. Long before the debacle of President Bill Clinton's 1993 "BTU Tax" proposal and Liberal Party Leader Stéphane Dion's 2008 “Green Shift” proposal, virtually any form of direct cost imposition on energy consumption through taxation has faced vigorous political opposition (Harrison, 2012). Annual carbon tax proposals introduced in recent Congresses have rarely even advanced to the stage of committee review and hearings. This opposition has also extended to numerous efforts in both nations to make small upward adjustments in federal gasoline excise taxes established many decades ago.

Consequently, energy and climate policy in these neighboring federal governments has instead entailed a diverse range of policy tools that pursue "everything but" direct cost imposition through taxation, thereby running contrary to what most economists would endorse as superior policy design. These existing policies include regulations that tighten vehicular emissions through fuel economy standards (both nations), federal regulations on emissions from coal plants (operational in the United States and under development in Canada), and mandates to produce increased electricity from renewable sources through portfolio standards (29 states and four provinces), among others. These generally eschew the kind of explicit carbon pricing mechanism embedded in the idea of carbon taxes and represent a set of policy tools most economists abhor (Rabe, 2008).

Aside from a very small set of European Union member states, the North American carbon tax experience at the central level of government runs parallel to general experience among democracies in Europe, Asia, and Latin America. In short, this may reflect a combination of "good policy" with "bad politics," and with a few notable exceptions in recent years (Harrison, 2012; Lachapelle, 2011; Rabe, 2010), the entire issue of "the politics of carbon taxation" has been essentially ignored by the political science community. It may be correct to simply assume that carbon taxation is a nonstarter at the national level of democracies in advanced economies, barring a very unique-and perhaps even flukish-constellation of circumstances. The imposition of costs through energy taxation is likely immediate, visible, and salient, thereby capable of provoking strong negative reactions from 
consumers (Borick, 2010; Lachapelle, Borick, \& Rabe, 2012). Perceived benefits from such a policy may be difficult to discern and perhaps not calculable until future generations. Alternative approaches, such as regulation, tax incentives, and voluntary programs, may be far less efficacious in economic terms but are far more feasible politically for their near-invisible imposition of costs. As a result, carbon taxation may belong on a lengthy list of worthy policy ideas that simply cannot be expected to survive translation into actual policy through political deliberation. If accurate, this view makes carbon taxation unworthy of serious study by political scientists and other social science disciplines, thereby leaving economists alone to lament their fate.

This article revisits this issue and ultimately offers a modest amendment to the conventional wisdom that removes energy and carbon taxation from the table of what might be politically feasible. It demonstrates that there may be a range of ways to design tax or tax-like policies that can gain political support, particularly if attention is given to how to characterize the policy to the public and allocate funds that it generates toward tangible and popular purposes. Whereas most policy analysis of this issue has focused exclusively on the national level, this paper considers the question of American state and Canadian provincial willingness and capacity to use some form of carbon taxation in developing their own energy and climate policy initiatives. It considers a wide range of policy instruments that place some direct cost on the use of fossil fuels. With one exception, none of these policies constitute a pure form of carbon taxation at a scale large enough to realistically begin to significantly deter fossil fuel use. Indeed, many of these policies impose relatively modest costs, whether through creating a new policy or expanding an existing one. Many are averse to even using such words as "carbon," "climate," or "tax" in their official labels. Nonetheless, they collectively represent a body of carbon taxes or carbon taxation-like instruments that follow the playbook of economics and operate in one or more North American jurisdictions. They have all passed political muster in state or provincial legislatures or through ballot propositions and offer some creative linkages between cost imposition and benefit provision through concrete plans for use of funds that are generated. Subsequent sections review the political foundation of these policies and introduce a framework for examining different kinds of emerging approaches. The article includes a preliminary estimate of the actual carbon tax rates that some of these policies impose in practice, consideration of larger lessons that can be drawn from this body of policies, and exploration of emerging venues for possible expansion of this approach in North America and beyond.

\section{Slouching toward De Facto Carbon Taxes}

The evolution of American states and Canadian provinces into major innovators in climate-relevant energy policies is reflected in an expanding body of scholarly literature (Selin \& VanDeveer, 2009). These analyses examine the range of policies that have been put into operation and the underlying factors that have influenced their adoption. Many of these policies follow classic patterns of diffusion and direct linkage with economic development initiatives. Policy entrepreneurship has been identified as a central driver at the state and provincial levels as well as among local 
governments (Krause, 2011; Rabe, 2004). Some initiatives involve formal partnerships between multiple states and provinces, periodically operating across the 49th parallel.

The American state policy process moved earlier and more rapidly than the Canadian provincial process. In the American case, state climate policies generally embraced a mix of regulatory and voluntary approaches but avoided explicit carbon taxation (Rabe, 2008). Indeed, many of these policies attempted to downplay or minimize any costs and instead accentuated the anticipated combination of environmental and economic development benefits. In the case of popular renewable electricity mandates, one analyst notes that part of their political feasibility stems from the fact that "they come with no explicit price tag" (Carley, 2011, p. 271). In fact, any increased future cost from these mandates would likely be difficult to trace directly to the government mandate, thereby increasing its political attractiveness.

Canadian provinces were initially characterized as a climate laggard of sorts, but a number of them have moved actively in this policy domain in more recent years (Houle \& Macdonald, 2009). One careful comparative analysis concludes that states and provinces have reached "equifinality" in climate policy, whereby "the eventual responses at the middle tier share more commonalities than contrasts" (Burke \& Ferguson, 2010, p. 437). As in the American case, provinces tend to tailor policies to their own jurisdictional needs but with some larger common patterns emerging. In both instances, state and provincial policies are matched by a comparable blend of local government initiatives (Gore, 2010; Hoffmann, 2011; Krause, 2011), although this analysis focuses primarily on the former set of cases.

Both American state and Canadian provincial experience is linked by substantial constitutional authority to experiment with a diverse set of climate policies, if they are politically inclined to do so. This also extends to the option of taxation, as these neighboring federations have "carried tax decentralization" about as far as any other jurisdictions in the world (Bahl \& Cyan, 2011, p. 264). Consequently, there are very few formal restraints on states and provinces that might attempt to establish some form of a carbon tax, either devising a new instrument or building on established levies such as gasoline excise taxes. This provides a large set of cases to consider whether strong outward expression by many states and provinces of concern regarding climate change mitigation and alternative energy development have led to some use of the tool that economists have long embraced as the superior approach.

This analysis provides an inductive review of the energy and carbon taxation policy records of all American states and Canadian provinces and territories between 1997 and 2012, which corresponds roughly with the period of sub-federal domination of climate policy (Rabe, 2011). This included review of existing databases that examine all of these jurisdictions. For example, some analysis of gasoline tax trends is conducted on a cross-national basis under the auspices of the Motor Fuel Tax Section of the Federation of Tax Administrators, including annual trends in gasoline tax levels and details on particular tax procedures. This was supplemented by data from professional associations that operate in each of the nations. In other cases, review of published literature, databases from various think tanks, nongovernmental organizations, and specific state or provincial Web sites was 
conducted to allow for a survey of all jurisdictions. These reviews considered explicit taxes as well as a wide array of policy tools that impose a direct cost on energy consumption but are not necessarily characterized as a "tax." This included new policies enacted during this period at any level or increases in policies established after 1996. One central goal in this review was to explore whether there was a roster of sub-federal policies that would either meet the explicit definition of a carbon tax or would pass a functional equivalency test (Lachapelle, 2011, p. 116). It also examined the relatively small set of cases where there was serious consideration given to developing an explicit carbon tax, auction, or fee, including cases where such a policy was not enacted or remains pending. There remains, however, little previous analysis of this area and so work continues on developing a more reliable database over time. It is indeed possible that this analysis may have missed other policies that also impose a direct cost on energy consumption but may not have been generally thought of in this way.

\section{The C-Word and the T-Word: Toward an Understanding of Carbon Pricing Policy Labeling}

State and provincial governments have a near-infinite number of options in energy and climate policy, if they attempt to do anything at all. They also have strategic choices in framing and labeling these options as they consider adopting them as policies. Issue framing reflects the most common way that a policy issue has come to be understood in a particular political system. For climate change, proposed mitigation policies may either be framed as legitimate responses to an environmental threat, pursuit of an economic development opportunity, or something to be avoided due to its potential economic threat. If policies are adopted, they require specific labels. These may seem purely semantic and symbolic but instead give government authorities some latitude in the explicit language that will officially be used in publicly describing the policy (Rabe, 2004).

In theory, any policy designed to reduce greenhouse gas emissions might be labeled "climate policy." In turn, any policy designed to impose a cost on the extraction, refinement, and use of fossil fuels might be labeled a "tax." Indeed, a common definition for the word "tax" is a "pecuniary charge imposed by legislative or other public authority upon persons or property for public purposes." Combining these two ideas, one might confine any study of "carbon taxes" to those policies that explicitly utilize both of those labels. If those exact criteria were used, one would find a grand total of two policies, a rather ambitious carbon tax in British Columbia and a much more modest version in Quebec (Harrison, 2012). No such federal policy exists in the United States or in Canada. In turn, no state policy would fit these criteria, although three modest American local government initiatives would fit, namely carbon taxes enacted in Boulder, CO, San Francisco, CA, and Montgomery County, MD. ${ }^{1}$ One might readily conclude that carbon taxation was a highly peripheral activity in these two nations and that neither federal nor subfederal governments imposed prices on carbon.

Expanding the labeling options for policies provides a somewhat different picture, however. Governments might use the explicit label of taxation for one or more fossil fuel sources, presumably having the same impact on fuel usage as would 
Table 1. Carbon Pricing Policy Labeling: American and Canadian Sub-Federal Policies, 1997-2012

\begin{tabular}{|c|c|c|c|}
\hline & & \multicolumn{2}{|c|}{ Taxation Labeling* } \\
\hline & & Explicit & Implicit \\
\hline \multirow[t]{3}{*}{ Climate labeling** } & Explicit & $\begin{array}{l}\text { British Columbia carbon tax } \\
\text { Quebec carbon tax } \\
\text { U.S. local carbon taxes (cell 3) }\end{array}$ & $\begin{array}{l}\text { Regional Greenhouse Gas Initiative auctions } \\
\text { California (Western Climate Initiative) auctions } \\
\text { California climate fees/charges (cell 2) }\end{array}$ \\
\hline & Implicit & $\begin{array}{l}\text { Washington gas tax increase } \\
\quad \text { (cell 3) }\end{array}$ & $\begin{array}{l}\text { Public benefit funds } \\
\text { Social benefit charges } \\
\text { Electricity fees and surcharges } \\
\text { Alternative compliance payments (cell 4) }\end{array}$ \\
\hline & Indifferent & $\begin{array}{l}\text { Gas tax increases } \\
\text { Sales tax harmonization } \\
\text { Energy severance taxes (cell 5) }\end{array}$ & No policies (cell 6) \\
\hline
\end{tabular}

*Taxation labeling considers whether or not the energy cost imposition policy explicitly uses the word "tax."

**Climate labeling considers whether or not the energy cost imposition policy is characterized as climate-relevant due to potential reduction of greenhouse gas emissions.

an explicit carbon tax as it applied to that fuel. In fact, all state, provincial, and territorial jurisdictions have long sustained their own gasoline and diesel excise taxes, beginning with the first such tax in Oregon in 1919. A small set of these have increased their rates significantly in the past decade and a half, thereby imposing a higher de facto carbon price on gasoline and diesel. Thus, it is entirely possible to have an explicit tax on energy use but simply not use the word carbon (and, perhaps, be indifferent to any greenhouse gas impacts of the tax). At the same time, governments might establish a policy that in effect functions similarly to a tax on energy, with a particular focus on fossil fuels. They might (or might not) use the word "carbon" but might search for some synonym for the "tax-word" to make the policy less politically charged. Such options as "fees," "charges," "surcharges," "payments," and "premiums," among many others, are utilized in various states and provinces and will be further explored later.

The differences between these options begin to take some shape in Table 1. On the horizontal dimension, the state or provincial energy cost-imposition strategy is distinguished by its labeling. Tax and something-other-than-tax are the two options here. On the vertical dimension, the state or provincial policy has three distinct labeling options relevant to climate change. It might label the policy as an explicit climate policy tool, an implicit climate policy tool, or indifferent to climate consequences. An explicit tool will literally include the word "climate" or words "climate change" in its title and public documents related to the policy. Such a policy has the express intent of reducing greenhouse gas emissions. An implicit tool will not make such extensive reference to greenhouse gas impact but will make at least some explicit reference to potential climate impacts or climate-related uses of collected funds in public narratives explaining the rationale for the policy. An indifferent policy will impose the cost but make no demonstrable indication that the cost is being fully or partially imposed for climate-related purposes or that it might lead in some way to reduced greenhouse gas emissions. It might instead focus exclusively on other labels, with any impacts on greenhouse gas emissions purely incidental. As policy analyst Ian Rowlands has noted, "we have pronouncements on energy that seem largely oblivious to similar pronouncements on climate change (and vice versa)" (Rowlands, 2008, 
p. 307). Subsequent sections explore each of the six emerging cells in some detail. These provide further description of the labeling combination used therein and a review of some prominent case examples where relevant.

\section{Explicit Tax, Explicit Climate Change: Carbon Taxation}

Explicit use of the tax and carbon labels remains highly exceptional in states and provinces but may not be entirely dismissed as a political impossibility (cell 1, Table 1). Such an approach may require formidable policy entrepreneurship that is so committed to the policy idea that it is prepared to take significant political risks and move aggressively to seek enactment. This may follow the pattern in other policy areas where unexpected ideational triumphs occur. One prominent example is the American federal experience with economic deregulation in the 1970s and 1980s; despite enormous interest group opposition and little demonstrable public support, prominent political leaders embraced the consensus position that emerged from economists and pursued aggressive changes in sectors such as commercial aviation, telecommunications, and other areas of transportation (Derthick \& Quirk, 1985).

American state or Canadian provincial pursuit of explicit carbon taxation may require a political "perfect storm" of sorts, and this indeed was the case in British Columbia (Harrison, 2012). The province adopted such a tax in 2007, applied initially at a rate of $\$ 10$ per ton across fossil fuel sources. It then climbed in annual increments and reached a level of $\$ 30$ per ton in 2012 (see Figure 1). Applied to gasoline, e.g., the $\$ 30$ level will translate into a 27-cent-per-gallon tax, above and beyond existing provincial and local fuel taxes. ${ }^{2}$ As of 2012, the tax reached approximately $\$ 1.50$ per gigajoule of natural gas, $\$ 53$ per ton of coke, and $\$ 31$ per ton of peat. The overall impact, however, will likely be fairly modest in the electricity

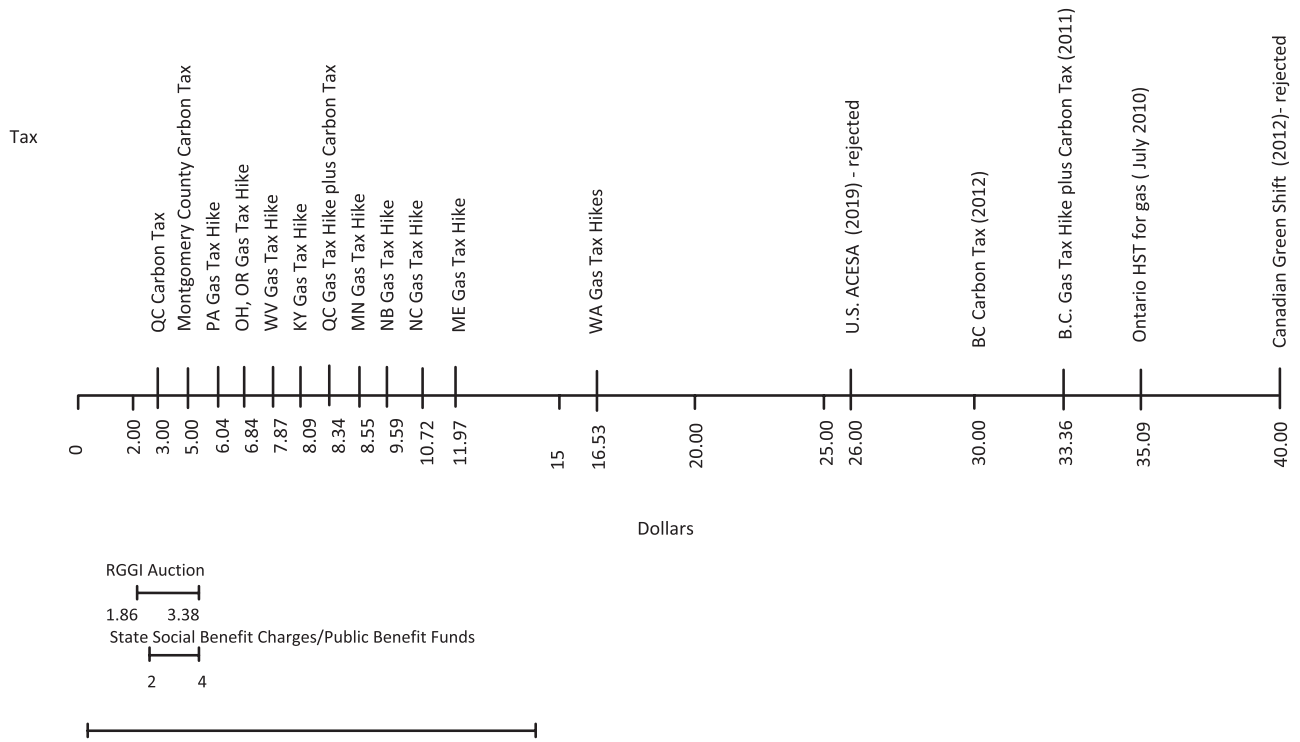

Figure 1. Sub-Federal Carbon Pricing Instruments in Canada and in the United States, 1997-2012 (Dollars per Ton of Carbon Dioxide Released) 
sector, as the province derives more than 90 percent of its supply from large-scale hydroelectric plants. The development of this tax reflected considerable ideational work by economists and other policy analysts, many of whom were based in British Columbia. However, this initiative was clearly the brainchild of then-Premier Gordon Campbell. A former Vancouver mayor who was elected premier in 2001, Campbell led his Liberal Party to reelection in 2005 and embraced carbon taxation the following year. Initially quite controversial, polling suggests a steady increase over time in support for the policy. Campbell won a third term at the polls in 2009 and campaigned in part on the environmental and economic desirability of the carbon tax approach. His resignation in 2011 was linked to other tax reform issues, namely the adoption of a harmonized sales tax in collaboration with the federal government; Campbell's successor, Christy Clark, continued to support the carbon tax. The primary opposition party in the province reversed its earlier opposition to the carbon tax in 2011, stating that it had erred in its earlier assessment. This leaves effectively no organized political opposition to the tax in the province.

It is difficult to understate the centrality of the premier's role in this case, as "change only happened when Premier Gordon Campbell was ready to act" (Burke \& Ferguson, 2010, p. 445). Some analysts have focused on a combination of personal experiences to explain Campbell's actions. These factors include the following: the onset of milder British Columbian winters that produced insect infestations that ravaged provincial forests; the convergence of grandparenthood and a wellpublicized drunk driving incident in producing a reexamination of his policy priorities as he approached the latter stages of his career; and the opportunity to use leadership on the carbon tax and related climate change issues to develop a national and even international reputation as a climate policy star. Other analysts have focused on more strategic considerations as drivers for Campbell. These factors include the following: strategic maneuvering of his center-right Liberal Party to outflank his primary opposition from the left-center New Democratic Party by taking the lead on a prominent environmental issue; the careful navigation of legislative ridings with some concentration of coal or natural gas in structuring the tax; and the opportunity to use the tax to bolster ties with aboriginal groups concerned about climate change.

Combined, these factors provided substantial impetus for Campbell to use his considerable authority as premier to push for a postelection embrace of the tax and then attempt to not only sustain the tax for a few years but to use it as a plank in his reelection campaign. Campbell clearly attempted to mitigate public opposition to the tax through a series of measures to return all of the revenues generated through carbon taxation to the general public. This began with rebate checks, known as "climate action dividends," to all provincial residents before the tax began to operate. It has continued with coordinated cuts in individual and corporate income tax rates and low-income households receive "climate action tax credits." Thus, the province returned all $\$ 848$ million generated by the tax between 2008 and 2011 and planned to continue to do so in subsequent years, while maintaining a provision to reduce the salary of the provincial finance minister by 15 percent if these revenue return mechanisms were not implemented. As environmental journalist Christa Marshall has noted, "The idea is to make the tax revenue-neutral for the govern- 
ment and innocuous to the economy overall, while forcing industries and consumers using the most fossil fuels to reduce emissions" (Marshall, 2011).

This linkage between cost imposition and benefit provision may be an important element in future carbon taxation initiatives, but the British Columbia experience has thus far not triggered the kinds of policy diffusion across states and provinces that have become common for many other climate policy tools. Small-scale replicas of the British Columbia policy have emerged in Quebec and in three American localities, with carbon tax funding most commonly used to cover the costs of climate-related programs. At least six states have examined the British Columbia option in legislative hearings or studies, but only California has seriously considered a comparable proposal. In 2009, the California Commission on the 21st Century Economy endorsed a tax of approximately $\$ 20$ per ton on all carbon-based transportation fuels and raised the possibility of linking such a tax with reductions in other "distortionary" taxes such as income and general sales. A wide range of economists expressed support for this proposal, one of many fiscal reform ideas advanced by the commission. However, then-Governor Arnold Schwarzenegger and the California legislature decided to dismiss the proposal as they clearly preferred to continue pursuit of an existing set of climate policies that featured less direct cost imposition strategies, including the emissions trading provisions of the 2006 Global Warming Solutions Act.

No other state or province has since engaged in such explicit discussion over a high-level carbon tax despite the active exploration of new revenue sources in many capitals in recent years amid mounting budgetary constraints. Indeed, explicit carbon taxation set at a level that might actually deter fossil fuel use and reduce greenhouse gas emissions may remain a political long shot in states and provinces, barring some unique configuration of political factors. This would also be consistent with experience outside the United States and Canada, which suggests that it is generally difficult to surmount these kinds of barriers (Cass, 2006). Instead, it appears that alternative approaches might be more feasible politically, including cases where labeling served to modify such terms as "climate" or "tax" with more palatable options.

\section{Explicit Climate, Implicit Tax: Auctions and Fees}

One possible labeling reconfiguration entails maintaining explicit reference to the climate goals of a policy. However, it would avoid the carbon tax label by characterizing policies that imposed costs and thereby attempted to deter fossil fuel use as something other than a tax. This could lead to a number of permutations, but two distinct options have emerged, particularly concentrated among American states in recent years. As a result, a growing set of state governments collect revenue from the consumption of fossil fuels for the express purpose of deterring climate change but assiduously avoid referring to these policies as taxes (cell 2, Table 1).

Perhaps the most prominent initiative to combine such a labeling strategy has involved modification of traditional approaches to emissions trading when applied to carbon. Under more conventional cap and trade policies used in both the United States and Canada, governments allocate allowances to large emission sources and encourage creative and cost-effective efforts to reduce emissions. However, these 
allowances are linked to previous emission levels and are allocated without cost. Consequently, firms might have to make efforts to reduce their emissions, such as investments to purchase and operate abatement technology, but do not transfer revenue to the government to purchase emissions allowances.

This changes dramatically, however, when government auctions the available allowances to the highest bidder. Auctioning is used in numerous areas of public policy, with a near-infinite number of possible permutations and goals (Whitford, 2007). Applied to carbon emissions, firms must bid successfully to secure allowances and thereby transfer any funds to a government agency. In short, firms must pay governments to continue to use fossil fuels, either reducing their margin of profit or passing those costs on to customers. However, it is not necessary to describe this mechanism as a tax.

Such an approach was formally unveiled in 2008 by the ten northeastern states that formed the Regional Greenhouse Gas Initiative (RGGI). The regional entity had agreed earlier in the decade to develop a cap and trade zone for carbon produced in the electric utility sector, hopeful that it might acquire other state or provincial partners over time or be adopted as a federal model. For several years, multistate negotiations worked through the considerable details involved in launching North America's first emissions trading program for carbon. Allowance allocation and apportionment was first formally addressed in 2004 through a regional workshop, but many key details remained open to debate. Over time, the option of auctioning allowances rather than distributing them for free gained favor (Raymond, 2010). This shift responded in part to the troubled early experience with free allowance allocation in the European Union Emissions Trading Scheme as well as the recognition that this approach could generate revenue for climate programs while avoiding the word tax.

States ultimately were given considerable latitude in deciding what to do with their share of allowances. With some parallels to the Gordon Campbell experience in British Columbia, one RGGI state governor moved promptly following an election to embrace the principle of auctioning. During his 2006 campaign, Massachusetts Democrat Deval Patrick vowed to reverse the decision of his predecessor, Mitt Romney, and commit the state to the RGGI process. However, shortly after his election, Patrick announced that Massachusetts would auction 100 percent of its RGGI allowances and apply those funds directly to a range of energy efficiency and renewable energy programs connected to overarching state climate goals. As political scientist Brian Cook has noted, "The governor had the independent legal authority and the political power gained through a strong electoral victory and veto-proof party control of the state legislature to overcome the resistance of the concentrated cost bearers" (Cook, 2010, p. 480).

The Patrick decision had a domino-type effect, leading to diffusion of the auctioning idea to each of the other RGGI states. Consequently, regional auctions began quarterly in 2008, with initial allowance bids in excess of $\$ 3$ per ton, producing revenue that would be transferred to each participating state. The bid price gradually declined to a level below $\$ 2$ per ton and has leveled out at the $\$ 1.86$ price floor set by the RGGI states (see Figure 1). This low price reflected an unexpected development, whereby the Great Recession triggered substantial decline in regional demand for electricity, consequently placing utilities around the Northeast at least 
25 percent below their carbon emission caps. As a result, they did not need to make adjustments to remain well within the limits of the gradually declining cap and yet still had to engage in quarterly auction bidding in order to secure allowances and continue to operate. Over time, the RGGI began to appear less as a climate program focused on emission trading and more as a climate program that found a mechanism to generate revenues to cover some of the costs of related state climate programs. This process has proven increasingly controversial, particularly once a few states decided to shift some auction revenues into general funds. New Jersey formally withdrew from the regional pact in 2011 after Governor Chris Christie derided it as a "failure" and a few other states have considered similar steps. Nonetheless, the RGGI continues to operate and proposals emerged in 2011 that would either set a more ambitious reduction goal or extend the program to other sectors, all with potential consequences for its revenue-generating (albeit nontax) capacity. The RGGI generated more than $\$ 850$ million in revenue in its first three years of auctioning, with the vast majority of those funds transferred directly to state climate-related initiatives.

At the same time that the RGGI added the concept of carbon auctions to the lexicon of revenue-generating climate policy tools, other states began to explore options for establishing various "fees" and "surcharges" that would be used to fund directly related climate policy activity. California may be the continental champion in terms of the sheer range of "climate fees" that it has considered in recent years. Any consideration of a carbon tax in that state, as noted earlier, would likely face substantial political opposition. It would also have to clear California's unique super-majoritarian constitutional hurdle for passage of any new tax or tax increase, namely a two-thirds vote in each chamber of the state legislature and then gubernatorial assent. As a result, legislatures and agencies have developed a wide range of fees and surcharges to cover various governmental costs in recent decades, essentially operating as a tax but literally avoiding that term to bypass constitutional and political stumbling blocks. Climate change would prove no exception to this pattern.

Under the 2006 California Global Warming Solutions Act (AB 32), the California Air Resources Board (CARB) was given a lead role in policy development but no secure set of funds for implementation of the cap and trade and other regulatory programs envisioned in the legislation. However, according to a CARB spokesperson, the law "gave CARB broad authority to set and collect fees, including fees for administrative costs." This led CARB to explore, with some support from legislative leaders, a dizzying array of potential fees and other possible revenue-generating methods to cover climate program operations and, in some instances, expand them. These options included the following: a "broad-based, economy wide fee" on fossil fuels; surcharges on vehicles with high greenhouse gas emissions; "surcharges on high global warming-potential gases"; a special fee on greenhouse gas-emitting facilities; congestion pricing with fees for driving during peak hours on designated roads; indirect source rules for new development projects, including a charge on project developers to mitigate greenhouse gas emissions generated by their projects; pay-as-you-drive fees that would produce state revenue and also link insurance premiums with driving distances; a charge on water bills to cover the costs of improving energy efficiency in water distribution and use. All of these proposed 
policies were explicit that reducing greenhouse gas emissions would be one of their primary purposes.

CARB was not alone in this policy-exploration process in California, as new fees and related programs were considered for other state government units with a role in climate policy. For example, legislation passed both chambers in late 2008 that authorized the California Public Utilities Commission to establish a "greenhouse gas mitigation fee" on all electricity use in the state, with the proceeds intended for establishing a California Climate Change Institute under the auspices of the University of California system. This bill was vetoed by Schwarzenegger, not due to the fee but rather the legislation's exclusion of other segments of the state's higher education system as potential funding recipients.

Any prospect for establishing one or more of these fees was likely halted through a 2010 ballot proposition. At the same time that California voters decisively rejected a proposition (23) that would have essentially gutted $\mathrm{AB} 32$, they also endorsed a proposition (26) that would set the same super-majoritarian approval for fees as is already in place for taxes. The two-thirds standard in both chambers has generally served to chill much of the discussion of creating new fees or expanding existing ones. However, CARB Administrator Mary Nichols has continued to argue that a wide range of potential fees or fee expansion may not be exempt from this new categorization and several fee options remained under active exploration in 2012.

This likely impediment to fee and surcharge development, however, was not the end of the California climate experiment with revenue-generating policies that are explicit concerning climate change intent but averse to the word taxation. Under AB 32, California continued to move toward development of a carbon cap and trade system, with the possibility of joining a number of states and provinces (including British Columbia) under the regional Western Climate Initiative (WCI). The California program and the WCI have some parallels to the RGGI but address a much broader set of greenhouse gases and set much more ambitious emission reduction targets. The potential impact on emissions could far exceed the RGGI if implemented. The use of auctioning could also produce revenues in excess of any climate program currently in operation in either the United States or in Canada given the scope of the California economy.

Very similar to the RGGI experience, California and its WCI partners have attempted to assemble the architecture of a carbon cap and trade system over several years. One area receiving prolonged exploration has been the issue of allowances and whether or not to build on the RGGI experience with auctioning. This question has been central to ongoing state development of perhaps the most complex and confusing title in the lexicon of governmental efforts to consider a carbon tax or equivalent: The "Order Instituting Rulemaking to Address Utility Cost and Revenue Issues Associated with Greenhouse Gas Emissions" (OIRAUCRIAGGE). The OIRAUCRIAGGE adds new complexity to the range of American policy acronyms and has examined many structural elements in establishing an auctioning system while fielding inquiries and advice from a dizzying array of interested parties. California has generally supported some initial use of auctioning, but set initially at a low level of approximately 10 percent of total allowances. This percentage is designed to climb over time as the emission cap becomes increasingly stringent. 
Once California's underlying legislation was preserved via ballot proposition, its cap and trade system was supposed to begin operation in January 2012. However, the sheer complexity of its undertaking and the intense battles over auctioning has delayed that launch for at least one year. CARB instead launched a cap and trade "practice round," including auctions, in 2012, delaying the formal launch until January 2013. Participation of other state and provincial WCI members appeared increasingly uncertain by 2012, in large part due to declining support from incoming elected officials in more recent years and the complexity of passing authorizing legislation and regulation. Perhaps the biggest single point of contention in California remains the allocation of revenues under any auctioning process, as demonstrated in one extended litigation battle. In this case, environmental justice organizations contend that the proposed cap and trade arrangement would harm the communities they represent and thereby warrant substantial transfer funds to these communities via the auctioning mechanism (Association of Irritated Residents v. CARB). Other legal challenges have emerged from key industries in California and neighboring states. Amid these uncertainties, California continues to build on the "explicit climate, implicit tax" model for carbon cap and trade initiated under the RGGI.

\section{Implicit Climate, Explicit Tax}

It is also possible to envision a reversal of the carbon pricing strategy explored in the prior section. Under this scenario, explicit taxation would be initiated or expanded in fossil fuel use, thereby serving as a deterrent to consumption. However, it need not necessarily be explicit concerning greenhouse gas ramifications or even driven significantly by climate concerns. In such cases, any climate change mitigation may be largely implicit, perhaps noted as a potential side benefit through use of funds for climate-friendly projects but not a primary driver behind enactment (cell 3, Table 1). Virtually no case examples were found reflecting this combination, although a two-step wave of gasoline excise tax increases in Washington State between 2003 and 2008 has some parallels. When combined, these two tax hikes generated the largest gasoline tax increase of any state or province during the past decade and a half and made at least some explicit reference to potential climate benefits in public documents in conjunction with its second and largest increase.

Washington State has had an active presence in climate policy, including participation in cap and trade development under WCI auspices. It also has a longstanding history of working collaboratively with neighboring British Columbia on a range of environmental and energy matters. In turn, Gordon Campbell has noted his unusually strong cross-border partnership during his premiership with Washington Governor Christine Gregoire. Ironically, Washington moved before British Columbia on major energy taxation, though with a more modest levy that was applied only to gasoline and diesel fuel.

Washington's primary medium for increasing fossil fuel prices was its gasoline excise tax, driven by a growing recognition that the state tax set at 23 cents per gallon in 2002 was not producing sufficient revenue to meet basic infrastructure repair costs and assure maximum return from federal matching dollars. This is indeed a common problem across most states, as the cents-per-gallon approach of 
the tax and general support for low rates has led to a stagnant transportation revenue base and jeopardized federal funds linked to state effort. Similar issues emerge in Canadian provinces, though provincial and federal gas tax revenue are tied less exactly to transportation and more funding has been made available from other revenue sources. In 2003, Washington's legislature and Governor Gary Locke approved a "nickel package," increasing the gasoline tax by 5 cents over a two-year period, with the proceeds linked directly to 130 specific transportation projects spread across the state. However, this soon proved inadequate and Gregoire proposed a 9.5-cent increase two years later. The proposal was approved narrowly by the legislature and signed into law in April 2005; it survived a ballot proposition by a 55 to 45 percent vote in November.

These dual increases gave Washington the largest gasoline tax in the United States, reaching 37.5 cents per gallon once fully phased in. This constituted an increase of $\$ 16.53$ per ton in carbon dioxide emissions from gasoline, far greater than all other state climate policies including the RGGI auctions for electricitysector emissions (see Figure 1). The Washington policy promised substantial new revenue for a wide range of transportation initiatives to be undertaken over the next two decades, which was the dominant factor behind enactment. Both the legislation and the fight against the ballot proposition represented an unusual coalition of business and environmental leaders as well as some legislative collaboration across partisan lines.

In contrast to British Columbia, there was little explicit discussion of potential climate impacts of such a tax or linkage with existing state climate programs. However, state officials did make some public reference to reduced greenhouse gas emissions as a supplemental benefit, particularly from new initiatives in mass transportation and congestion reduction, contrary to all other gas tax increases that were examined between 1997 and 2011. Whereas most significant state gasoline tax increases in recent years have been allocated almost exclusively to highways, Washington proposed a "transportation partnership program." This included a farreaching set of 247 projects that cut across modes of transportation and offered new investments in rail and ferries that were directly linked to state climate policy strategies. Consequently, this can be characterized as a policy in which the tax word was front and center but climate benefits were largely implicit through revenue transfer to climate-friendly projects.

There are at least four other lessons from the Washington State experience in considering key design features of a policy that expressly increases energy taxation despite political risks, most of which offer some distinct parallels with the British Columbia carbon tax experience. First, Gregoire paralleled Campbell's role as a strong and enthusiastic supporter of the second and larger of the two increases. This included not only working in a legislative context to secure passage but leading the opposition to a ballot proposition in subsequent months. Second, Gregoire and her allies matched the British Columbia model with a detailed proposal in advance of enactment that set forth how all funds acquired through the tax increase would be utilized. Whereas British Columbia offered visible mechanisms for direct revenue return to the citizens, Washington countered with a remarkably detailed plan outlining both broad transportation and environmental goals and specific projects that would be pursued. Third, Washington chose to mitigate the pain of tax 
increases by phasing them in over four years, similar to the British Columbia experience, beginning with a three-cent hike in 2005 and concluding with a 1.5cent hike in 2008. Fourth, Washington chose to use a nontax label to secure additional transportation revenue through the same legislation, namely a trio of "fees" that collectively added about one third to the total amount of new revenue that would be generated. These included a "vehicle weight fee" on passenger cars, an increase in the "light truck weight fee," and an annual "motor home fee." Indeed, this final point shifts at least part of the Washington strategy into the implicit tax, implicit climate category, where it has considerably more company.

\section{Implicit Climate, Implicit Tax}

State and provincial governments may also explore a wide range of policy tools that could combine reduced greenhouse gas emissions linked to cost imposition while being implicit in use of such labels as "climate" and "tax" (cell 4, Table 1). As the Washington State experience suggests, the use of the term "fee" or various synonyms may be illustrative of a larger and stealth-like set of policies that in essence parallel carbon taxes. Both states and provinces have increasingly turned to fees or equivalents in recent years, including a great many linked to energy, climate, and environmental concerns. Water and sewer use, solid waste recycling and garbage pickup, and cleanup of leaking underground storage tanks are commonly funded through some combination of sub-federal fees in both Canada and the United States. As political scientist Michael Pagano has noted, "The rationale . . in support of the adoption or extension of user fees is that an increase in fees is an understandable market price action and generates less taxpayer (fee payer) hostility than a tax increase and that it tends not to be subject to tax limitations, thereby making it more accessible" (Pagano, 2010, pp. 121-122).

Electricity generation and use may be a particularly ripe target for a fee-based approach. Electricity consumption is generally paid through monthly bills that often vary markedly depending upon use in a particular period. In contrast to gasoline, where costs per gallon or liter are highly familiar given the large and visible signs that are standard fare in service stations, electricity costs per kilowatt hour or equivalent are likely less well-known. There is far less option for choice in purchase of electricity versus gasoline and most potential taxes and fees added to a residential and commercial electricity bill are often buried in small type if included at all. Consequently, it is not at all clear if consumers even read these bills or make much of a consumption adjustment if a small tax is added. Moreover, adding a less-combative word such as "fee" might further diminish political opposition.

Indeed, this seems to be the very approach taken in establishing a growing set of fees developed in recent years for electricity bills, although these do not generally discriminate between carbon and non-carbon sources. The primary goal of these fees appears to be securing a credible source of funding for energy efficiency and alternative energy programs, with the intent of finding some word other than "tax" to describe their cost-imposition strategy and not provide any explicit consideration of greenhouse gas emission impacts from the policy. In Ontario, for example, a 2010 provincial document with the snappy title of "Ontario Regulation Made under the Ontario Energy Board Act, 1998, Assessments for Ministry of Energy and 
Infrastructure Conservation and Renewable Energy Program Costs” outlines a plan to establish a $\$ 4$ annual fee on all electricity bills. This fee was expected to generate $\$ 53$ million to cover some of the costs of Ontario energy efficiency and renewable energy programs. It was designed to be reassessed annually, though it has proven controversial and also raised some constitutional concerns (Alarie \& Poschmann, 2010).

States may have moved into this arena somewhat earlier and more aggressively, with at least 18 having developed some parallel version of the Ontario fee. Many of these impose a higher charge than Ontario though likely not at a level sufficient to influence consumption significantly or perhaps even trigger awareness of the existence of the policy. These are known variously as "public benefit funds," "social benefit charges," or "public good charges" that create a "cross-subsidizing mechanism that taxes regular electricity consumption and subsidizes energy efficiency" (Carley, 2011, p. 283). California, for example, has a series of these programs and they collectively generate about one billion dollars per year for various energy efficiency programs. Oregon sets a 3 percent "public-purpose charge" on all state electricity bills, whereas Michigan has established a \$3 "renewable energy surcharge" that is applied to each monthly bill. Both states divide funding between renewable energy and energy efficiency programs, as do others. Connecticut, for example, has established separate fee rates for these two purposes, with a \$.001/ kWh fee that directs proceeds to the Connecticut Clean Energy Fund for renewables and a separate $\$ .003 / \mathrm{kWh}$ fee that directs proceeds to the Connecticut Energy Efficiency Fund (S. Federspiel, unpublished data).

Much of the funding from these various fees and charges is linked to energy programs that are elements of state climate policy strategies. However, one finds no evidence that these funding programs were launched with any explicit reference to climate impacts and all eschew the tax word in favor of some other label. They consequently suggest a stealth-like quality, set at very low levels so as likely to simply not be known by many consumers and averse to such specific labels as "climate" and "tax." In all likelihood, they impose a modest carbon price and generally do not discriminate between setting costs on carbon and non-carbon sources. These examples may well be supplemented by a range of additional fees or equivalents. For example, the renewable electricity mandates that operate in a growing set of states and provinces generally make some provision for "alternative compliance payments" if renewable target levels cannot be reached in a given period. A number of jurisdictions have increasingly faced difficulties in hitting these levels, in part due to unexpected conflicts over renewable energy siting proposals. Consequently, this can trigger payments that are generally directed at renewable energy programs, thereby constituting yet another example of an implicit carbon and implicit tax approach.

\section{Indifferent Climate, Explicit Tax}

Ironically, there may well be state and provincial policies that could impose a substantial carbon price on fossil fuels and make no bones concerning the fact that they are taxes. However, these generally are not thought of as having a link to climate policy, either at point of creation or expansion, and states do not calculate 
potential greenhouse gas emission impacts when considering tax rate changes (cell 5 , Table 1). At least three distinct forms of such an "indifferent climate, explicit tax" are currently in operation in one or more sub-federal jurisdictions in Canada and in the United States. Two of these are exclusively focused on securing governmental revenue through direct taxation of fossil fuels, whereas one places energy into a larger taxation package rather than singling it out. Looking ahead, these types of cases may well be the most likely future mechanism for increasing a carbon price in coming years, even though any formal linkage to climate change would likely be tenuous at best.

Back to the Gas Tax-Aside from the Washington State experience, no state or province has linked increases in gasoline taxes to climate concerns. Indeed, the proliferation of state and provincial climate action plans often give no indication that these taxes even exist. Nonetheless, all 60 of these jurisdictions have retained these excise taxes and generally refrained from any rate reduction in recent decades. Mean state and provincial excise taxes have remained greater than their federal excise counterparts over the past two decades (18.4 cents per gallon in the United States and 10 cents per liter in Canada) and there are nine states and three provinces that have increased their gasoline tax rates by more than 5 cents per gallon (or per liter equivalent) between 1997 and 2011. These increases are equivalent to increased carbon prices of between $\$ 7.21$ and $\$ 16.53$ per ton of carbon dioxide (see Figure 1). ${ }^{3}$ Actual increases have included 10.5 cents per gallon in Maine, 9.4 cents per gallon in North Carolina, and 2.3 cents per liter in New Brunswick. Significant gas tax increases in British Columbia and Quebec are primarily attributable to implementation of their respective carbon taxes.

In some respects, it is surprising that these rates have held constant and, in some instances, expanded given the extreme consumer antipathy to gasoline price increases. As journalist James Surowiecki has noted, "Gas prices are literally the most visible prices we have; you can't take a drive without seeing huge signs reminding you how much gas costs" (Surowiecki, 2011). There have indeed been numerous proposals to reduce or suspend these taxes, particularly in the face of major gasoline price spikes, but these have rarely been undertaken in individual states and provinces. The two exceptions to this pattern involve major tax increases in the early 2000s in Prince Edward Island (PEI) and New Brunswick, which were later scaled back somewhat amid partisan shifts in governmental control. In PEI, for example, a 13-cent-per-liter rate jumped to 19.5 cents in 2005 and as high as 20.4 cents the following year, reaching the highest level of any North American gas tax, before being scaled back to the 15 -cent range in more recent years. ${ }^{4}$

One key factor in sustaining political support for these taxes has nothing to do with climate and environmental protection and everything to do with transportation. The American gas tax system applies all of its revenues toward transportation, with the vast majority of that funding allocated to maintaining and building roads. This linkage has remained firm since the 1950s when President Eisenhower decided to fund the Interstate Highway System through federal and state gas taxes rather than tolls or other options (Mohl, 2003). In Canada, the federal share of gasoline taxes is not as tightly concentrated on highways and transportation, but the provincial components go overwhelmingly to this purpose. This provides a direct 
linkage between cost imposition and benefit provision and the public demand for quality transportation venues sustains support for the tax. In turn, growing need for revenue to sustain and expand that system provides impetus to consider increases. One study of the framing used to generate support for gas tax increases notes concern over crumbling infrastructure, need for long-term transportation reliability, and economic boosts from infrastructure investment (Watts, 2010) but does not find greenhouse gas reduction or other environmental impacts to be policy drivers.

Cases such as British Columbia and Washington State remain taxation outliers and yet a nontrivial set of states and provinces have found ways to increase gasoline taxes over the past decade and a half. Interestingly, the majority of these are not generally characterized as state and provincial leaders in climate policy development; a number of them (such as Kentucky, North Carolina, and West Virginia) have generally done little or nothing to attempt to reduce greenhouse gas emissions. Instead, they have been drawn into consideration of gasoline tax increases by other factors, most notably transportation revenue needs. One fairly common mechanism to minimize the pain of any tax increase has been a phased-in process, either through initial statutory design or some form of annual or semi-annual indexation to allow for inflation adjustment (Federation of Tax Administrators, 2010). ${ }^{5}$ Indexation has proven the most common method, usually through application of consumer price adjustment to some portion of the tax. In Maine, for example, this has generated steady increases from 19 cents per gallon in 2000 to 29.5 cents per gallon in 2011, while the North Carolina tax jumped from 23.1 cents to 32.5 cents in the same period (L. DeCarolis, unpublished data). This pattern actually bears some resemblance to the phasing in of carbon tax implementation in Quebec and British Columbia, albeit with the latter increases at a considerably higher rate as noted earlier. Looking ahead, the issue of gasoline tax rates or comparable programs is increasingly on the agenda of state and provincial governments facing enormous demand for transportation system improvements amid resource scarcity and growing uncertainty over future federal roles. These steps may be indifferent to potential greenhouse gas emissions limits but could, in effect, alter the actual carbon price that governments impose through various taxes.

Extended Sales Taxes-States and provinces feature dramatic variations in their general sales taxes, including scope of coverage and the related question of whether these taxes extend to various forms of fossil fuel use, such as transportation fuel and electricity generation. Economists have long noted that sales taxes tend to be loaded with loopholes and exemptions, including highly uneven treatments of various goods and services. Many champion a transition toward a broader tax that covers more goods and services in an equitable way and lowers overall rates to retain revenue neutrality. States and provinces approach electricity taxation in highly varied ways, with no clear counterpart to gasoline excise taxes. For electricity, the differential status of power intended for commercial and residential consumption routinely surfaces as a divisive issue, as do numerous other exemptions and equity considerations. Existing electricity taxation also tends not to differentiate between fossil and nonfossil fuel sources and is often exempted when generators are public corporations. At the same time, electricity taxes are frequently embedded implicitly 
into regulated rates and not easily understandable. As two careful analysts of this topic note, "Since electric utility bills generally do not indicate these tax obligations, the general public is largely unaware of the tax burden" (Howe \& Reeb, 1999). In short, there is far greater variability among individual states and provinces on the structure of electricity taxes than those used for motor fuel. This variability and lack of transparency has indeed opened the door to the kinds of electricity fees and charges noted earlier, although it also makes the issue of electricity a major theme whenever discussion of sales tax reform emerges. Even the more settled arena of motor fuel taxation can be revisited in this context, with the possibility of adding an expanded sales tax to an established excise tax.

Expansion of the set of goods and services covered under a sales tax or the transformation of traditional sales taxes into value-added taxes could serve to alter established taxation quite dramatically. This issue has surfaced periodically in American fiscal reform discussion but has emerged far more saliently in Canada, following the 1991 creation of a federal Goods and Services Tax (GST). The GST fostered extended consideration among provinces of transforming extant Provincial Sales Taxes (PSTs) into Harmonized Sales Taxes (HSTs), which work in close concert with the federal GST. Under such a transition, it is conceivable that energy could be added to the definition of taxable goods and services, leading to a significantly higher de facto rate of energy taxation than ever before and an establishment of a new indirect carbon price for fossil fuels. Among the provinces, Nova Scotia, New Brunswick, and Newfoundland have previously adopted an HST and Ontario and British Columbia are in relatively early stages of this transition.

The consequences for energy pricing may be particularly salient, however, in the Ontario case, given its decision to explicitly expand taxation of several energy sources as well as many other goods and services that were previously exempt from the PST. Nonetheless, there has been no explicit link between this tax and provincial climate goals in public documents and presentations, with Ontario's most visible climate policies remaining its planned closure of coal-fired power plants, membership in the WCI cap and trade development process, and a mixture of renewable energy initiatives. Thus far, other provinces have been less open to such expansive inclusion of energy under an HST transition. British Columbia, for example, technically does apply its HST to motor fuel but refunds it at the point of sale due to the existence of the provincial carbon tax. Electricity is exempted via a credit and rebate program. Several other provinces lack carbon taxes but also exempt motor fuel and electricity from their PST or HST.

Ontario maintained its 8 percent tax rate from its PST when transitioning into the HST. However, a primary change was the marked expansion of what is covered under the tax. Gasoline, electricity, and home-heating fuels were brought under HST auspices as were domestic air, bus, and rail travel originating in the province, and even taxi rides. In addition, a wide range of personal services were now covered under the tax, including real estate commissions, legal services, funerals, haircuts, and golfing green fees. Other services such as child care and medical care were exempt. As economist Michael Smart has noted, the HST represents "an increase in taxes levied on final consumer transactions through base broadening" (Smart, 2011, p. 3). The province attempts to offset the increased sales tax burden through comparable reductions in income tax burden. As in the case of the British Columbia 
carbon tax, tax creation went hand-in-hand with linked reduction mechanisms. In turn, some of the added tax burden was offset through rebates characterized as "Clean Energy Benefits."

Initial assessments of the application of the HST to fuel in summer 2010 indicated an immediate gasoline price jump close to the full added tax rate of 8 percent. Since that early stage, however, it appears that this added cost actually declined somewhat, with gasoline distributors "absorbing some of the tax into short-run profit margins as they learned about consumer reactions to the price increases" (Smart, 2011, p. 13). Consequently, it remains difficult at this early stage to discern the actual impact of the tax for gasoline or other energy sources. Nonetheless, conversion of the range of estimated price increases linked to the HST thus far for gasoline place this tax potentially at the high end among states and provinces in imposing a price per ton on released carbon dioxide (see Figure 1).

The long-term political viability of this tax is none too clear. In British Columbia, Gordon Campbell's approval ratings plummeted after he advanced an energyexempt version of the HST. The premier who ran successfully for reelection on a carbon tax platform was forced to resign after adopting sales tax reform. In Ontario, parties to both the left and the right of the governing Liberals made repeal of the energy applications of the HST a central part of their campaign platforms in 2011 elections. The Liberal Party narrowly retained power but began to explore possible HST repeal for home heating fuel in 2012. This political challenge is further illustrated in the American context, where broadening the base of the sales tax has long had considerable support from policy analysts and there has been precedent in some states to begin to expand the definition of eligible transactions. However, major laws to expand sales taxes to a large range of services in Florida and Michigan faced intense political opposition and rapid repeal. In Michigan, 2007 legislation extended the sales tax to more than 100 services, although exempting energy, offering a half-cent reduction in overall rates. However, it was repealed on the very day it was to take effect in the face of sustained public outrage. As one Republican legislator from Kentucky, a general supporter of this kind of shift, noted, "In truth, a lot of people like this concept of being taxed on what they use. Then they say, 'But please don't tax me because I'm a lawyer.' Or 'But please don't tax me because I'm a grass cutter, an accountant, anything'” (Davey, 2010). As a result, a base-broadening sales tax with potential application to energy remains an ideational possibility but few states or provinces give indication of following the path of Ontario.

Severance Taxes - There may, however, be one form of carbon cost imposition that is indifferent to climate impacts, entirely explicit and transparent in use of the word tax, and comparatively easy to move forward politically. In turn, state and provincial taxation of the "severance" of energy resources from the earth may quietly be evolving into one of the most significant ways to add to the price of carbon consumption. As long as a state possesses prized carbon resources within its borders and below ground level, the politics of energy taxation change markedly. There may well be relatively broad-based support for this kind of a tax, except for those extracting industries facing the costs. In this case, most of the costs are imposed on extracting firms and will likely be shifted to consumers of the fuels who live in other jurisdictions. 
Severance taxes have long been used by resource-wealthy states and provinces. In theory, they reflect a straightforward "flat rate per unit of measure," such as coal on a tonnage basis or oil on a per barrel basis. In reality, these taxes can become quite complex and can be designed in such a way as to yield substantial revenue while also offering incentive for continued exploration. Twenty-five states have one or more severance taxes for fossil fuels and at least six (Alaska, Montana, New Mexico, North Dakota, Oklahoma, and Wyoming) generate at least 10 percent of their state government revenue from these. New Mexico alone has the following set of severance taxes in place: Natural Gas Processor's Fee; Oil and Gas Ad Valorem Production Tax; Oil and Gas Conservation Tax; Oil and Gas Privilege Tax; and Oil and Gas Severance Tax. Provinces are similarly active in this arena, with Alberta, Saskatchewan, Newfoundland, and British Columbia particularly adept at using these taxes to provide a sizable portion of their annual revenues (Lecours \& Belard, 2010).

Perhaps the most entrepreneurial jurisdiction in this policy area is Alaska, which has long been dependent on severance tax revenues but enacted major reforms in 2007 that were designed to increase its revenue significantly. Most of the land used in Alaska for oil production is owned by the state, creating a lucrative system of leasing rights. However, the state supplements that with a series of other taxes, including a Petroleum Profits Tax that functions in essence similar to a windfall profits tax. Ironically, this very form of tax was discussed in the 2008 Presidential campaign, endorsed by Democrat Barack Obama but opposed by Republican John McCain. However, McCain's running mate, Sarah Palin was a central policy entrepreneur just one year earlier in moving forward the nation's most far-reaching windfall profits tax in Alaska. The 2007 Alaska's Clear and Equitable Share Act was passed in November during a special session of the legislature called by Governor Palin. This legislation increased the base tax rate from 22.5 to 25 percent of the annual production tax value of taxable oil and gas. For purposes of comparison, Norway sets its rate for a similar tax at 28 percent. However, Alaska also established a sliding scale to capture a larger share of company profits when prices rise above the level of $\$ 30$ per barrel. Consequently, this tax was aimed directly at maximum yield of revenue from Alaska's resource bounty. As envious analysts in Wyoming observed: "Alaska became the first state government to embrace an economic and geological reality: there is only a limited time to capture severance rates."

This tax increase was vehemently opposed by the oil and gas industry. However, Governor Palin gambled that they would be enticed into further exploration through a new set of tax credits and unable to leave the state because of its extraordinary fossil fuel bounty. In turn, the move proved to be very good domestic politics. Alaskans consume less than 1 percent of the energy that they produce, suggesting that any added costs due to the state taxes would be shifted elsewhere. At the same time, the new system immediately produced a substantial jump in state revenue, as the sliding scale kicked in amid an energy price spike. Alaska's annual revenues from the new tax and existing taxes and fees more than doubled to $\$ 10$ billion in 2008, the first year of the new tax. The state now generates approximately 86 percent of its total revenue from energy taxes, while also offering an annual dividend check to each resident of $\$ 2,000$. In 2008, Palin and the legislature approved a special $\$ 1,200$ supplemental payment to every Alaskan to help them 
cope with climbing gas prices, even though Alaska maintains the lowest gasoline excise tax rate among any state or province, at 8 cents per gallon. The state also continues to expand the Alaska Permanent Fund, whose proceeds passed the $\$ 40$ billion mark in 2011.

Several other jurisdictions in both the United States and Canada have looked to the Alaska model for maximal revenue extraction, with Alberta perhaps the best parallel among the provinces. Its own set of severance taxes fund, among other things, the Alberta Heritage Savings Trust Fund, which passed the $\$ 15$ billion revenue mark in 2011. However, perhaps the biggest future departure in the energy severance tax arena may emerge from the ever-expanding discoveries of natural gas and oil found in many sections of the United States and extended through hydraulic fracking techniques, including the massive Marcellus Shale formation. Many state governments cutting across partisan divides are turning to these finds and exploring a wide range of tax and fee programs. In some cases, these discoveries come in states with a long tradition of energy-based severance taxes, such as Oklahoma, Texas, and Wyoming. However, other cases involve states such as Maryland, Pennsylvania, and New York, which have never before established such taxes and have prompted both Democratic and Republican leaders to consider a wide range of possible taxes, fees, and royalty payments. Early public opinion analysis in Pennsylvania in 2011 demonstrated considerable public support for taxes on natural gas extraction, particularly under certain revenue use scenarios. None of this is motivated by a desire to address climate change but could use state taxation powers to add a hefty indirect carbon price, one potentially greater than that imposed by existing energy pricing mechanisms.

\section{The Future of Carbon Taxation Politics: Looking Ahead}

This article generally confirms the conventional thinking that the explicit taxation of the carbon content of fossil fuels remains a very difficult political sell. The American state and Canadian provincial experience is not that varied from national-level findings. Indeed, with the unique exception of British Columbia, it is difficult to find examples indicating a political willingness to put the most costeffective climate policy strategy explicitly into operation. That said, if one is willing to examine the carbon tax issue with greater elasticity, an unexpectedly large range of state and provincial case examples emerge. In some instances, relabeling policies to remove linkage with the idea of "carbon taxation" is evident, propelling a range of fees, charges, auctions, and payments. There is also some evidence of willingness to enact significant increases in existing energy taxes that establish an indirect carbon price, most notably gasoline excise taxes, but with little or no link to climate policy goals. Such elasticity reveals a surprisingly large and diverse array of policies that function, in effect, similarly to carbon taxes.

These policies vary markedly from one another, whether in design elements or the extent to which they embrace labels such as "climate" or "tax." However, one common design feature in many of the policies included herein is that they attempt to clearly state how revenues will be utilized. In some cases, this produces revenue neutrality, with a dollar-for-dollar shift from one expanding tax source to either another tax reduction or some form of transfer payment to citizens as compensa- 
tion. This is a uniting feature for such diverse policies as the British Columbia carbon tax, the Ontario harmonized sales tax, and the Alaska windfall profits tax. Another variation on this approach earmarks all of the revenue generated to a specific purpose, such as energy efficiency or renewable energy. This is a uniting feature for such diverse policies as the RGGI, the majority of public benefit funds, social benefit charges, and energy fees, as well as major gasoline tax increases in states such as Washington. This underscores the possibility of linking potential costs and benefits to bolster public support for energy and tax cost imposition initiatives. Such a strategy generally proves popular when tested in survey research.

This analysis also demonstrates that carbon cost imposition can take many forms, some of which may be hard to envision at this juncture. Auctioning carbon allowances under cap and trade surfaced in some early state policy documents but only gained serious attention through the RGGI process. California and the WCI entities must now decide whether to embrace that approach and expand upon it. Similarly, massive new discoveries of fossil fuels under the surface of North America open anew the issue of how to extract revenue from this potential energy bounty, possibly building on the experience of Alaska and Alberta and using taxation to essentially transfer costs to consumers who reside elsewhere. There remains little evidence, of course, that any of these programs will set their carbon tax rate (or equivalent program) at a level likely high enough to significantly deter fossil fuel consumption and thereby build a credible North American role in climate change mitigation. Instead, we are likely to settle for far less cost-effective tools and do so in a patchwork way, barring some shift in political dynamics that would allow cases such as British Columbia to emerge as the model rather than the exception.

\section{Acknowledgments}

Earlier versions of this article were presented at the 2011 Annual Meeting of the American Political Science Association and the 2011 Biennial Meeting of the Association for Canadian Studies in the United States. We are grateful to Douglas Brown, Benjamin Cashore, Shama Gamkhar, Monica Gallagher, Christopher Gore, Geoffrey Hale, Kathryn Harrison, Stephen Kelly, Erick Lachapelle, Leigh Raymond, Ian Rowlands, and two anonymous reviewers for insightful comments and suggestions. We also appreciate the research of Lyndsay DeCarolis and Seth Federspiel in examining some of the energy taxation options explored in this article. We also remain very grateful for grant support from the Canadian Faculty Research Grant Program and the support of Canadian Embassy colleagues Daniel Abele and Dennis Moore.

\section{Notes}

1 The Montgomery County tax, however, is facing possible repeal, after a June 2011 U.S. Court of Appeals ruling concluded that the tax was directed unfairly at a single firm, the lone coal-burning power plant operating in the county. The court declared that the action "is a punitive fee rather than a tax" in GenOn Mid-Atlantic LLC v. Montgomery County, MD.

2 Similar to many provinces, British Columbia allows local governments to add their own excise tax to the package and receive the revenue. Vancouver adds a 15-cent per liter tax, which is higher than the 
average tax ( 14.5 cents) among provinces and territories. Victoria adds a 3.5-cent-per-liter tax. The only other local government in Canada that has a gasoline excise tax is Montreal, set at 1.5 cents per liter.

3 According to economists Lucas Davis and Lutz Killian, drawing on the earlier work of William Nordhaus, a $\$ 35$ per ton carbon tax (United States) "implies a tax of approximately $\$ 10$ per ton of carbon dioxide." Carbon has an atomic weight of 12 atomic mass units, while carbon dioxide has a weight of 44, making one ton of carbon equivalent to 44/12 tons of carbon dioxide. Consequently, they note that the "carbon dioxide content of gasoline is approximately 0.0088 metric tons per gallon, so a $\$ 10.00$ tax per ton implies 8.8 cents per gallon." They conclude that a 10-cent-per-gallon gasoline tax increase in the United States would reduce vehicular carbon emissions by about 1.5 percent. Converted to the metric system, a $\$ 10$ tax per ton of carbon dioxide implies 2.4 cents per liter (Davis \& Kilian, 2011; Nordhaus, 2009).

4 The Prince Edward Island case is complicated by monthly recalculation of the rate. There have also been a few cases in which gasoline tax rates shifted markedly but these involved dollar-for-dollar equivalencies in adjustments with other sales taxes, resulting in no change in net tax burden on fuel purchase. Connecticut, California, and New York are prominent examples (DeCarolis, 2011).

5 Support for indexation should not be seen as politically risk-free. In Kentucky, a portion of the gasoline tax was placed under indexation in 1980. Some three decades later, an aide to then-Governor John Y. Brown was blasted in a U.S. Senate campaign in a mass media campaign deriding his earlier support for an "automatic gas tax." The indexation produced an overall increase of 12 cents per gallon in its first 30 years of operation.

\section{About the Authors}

Barry G. Rabe is the J. Ira and Nicki Harris Family Chair of Public Policy and the Arthur F. Thurnau Professor of Environmental Policy at the Gerald R. Ford School of Public Policy, University of Michigan. He is the director of the Center for Local, State, and Urban Policy at the Ford School.

Christopher P. Borick is Associate Professor of Political Science and Director of the Muhlenberg Institute of Public Opinion, Muhlenberg College.

\section{References}

Alarie, B., \& Poschmann, F. (2010). Ontario's green energy "fee": The trouble with taxation through regulation. Toronto, ON: C.D. Howe Institute.

Bahl, R., \& Cyan, M. (2011). Tax assignment: Does the practice match the theory? Environment and Planning C, Government and Policy, 29, 264-280.

Borick, C. P. (2010). American public opinion and climate change. In B. G. Rabe (Ed.), Greenhouse governance: Addressing climate change in America (pp. 24-57). Washington, DC: Brookings Institution Press.

Burke, B., \& Ferguson, M. (2010). Going alone or moving together: Canadian and American middle tier strategies on climate change. Publius, 40(3), 436-459.

Carley, S. (2011). The era of state policy innovation: A review of policy instruments. Review of Policy Research, 28(3), 265-294.

Cass, L. R. (2006). The failures of American and European climate policy. Albany, NY: State University of New York Press.

Cook, B. J. (2010). Arenas of power in climate change policymaking. Policy Studies Journal, 38(3), 465-486.

Davey, M. (2010). States seeking cash hope to expand taxes to services. New York Times, March 27.

Davis, L. W., \& Kilian, L. (2011). Estimating the effect of a gasoline tax on carbon emissions. Journal of Applied Econometrics, 26(7), 1187-1214.

Derthick, M., \& Quirk, P. J. (1985). The politics of deregulation. Washington, DC: Brookings Institution.

Federation of Tax Administrators. (2010). Motor fuels section uniformity project. Washington, DC: FTA.

Gore, C. (2010). Municipalities and Canadian climate change policy. Review of Policy Research, 29(1), 27-46.

Graetz, M. (2011). The end of energy. Cambridge, MA: MIT Press.

Harrison, K. (2012). A tale of two taxes: The fate of environmental tax reform in Canada and the province of British Columbia. Review of Policy Research, 29(3), 385-409.

Hoffmann, M. (2011). Climate governance as the crossroads. New York, NY: Oxford University Press.

Houle, D., \& Macdonald, D. (2009). Understanding the selection of policy instruments in Canadian climate change policy. Paper presented at the 2009 Annual Meeting of the Canadian Political Science Association, Ottawa, ON. 
Howe, E. T., \& Reeb, D. J. (1999). State and local electric utility taxes: Evolutionary taxation of a deregulating monopoly. American Journal of Economics and Sociology, 58(1), 115-128.

Krause, R. M. (2011). Symbolic or substantive policy? Measuring the extent of local commitment to climate protection. Environmental and Planning C, Government and Policy, 29, 46-62.

Lachapelle, E. (2011). Energy security and climate change policy in the OECD: The political economy of carbon-energy taxation. PhD Dissertation, Department of Political Science, University of Toronto.

Lachapelle, E., Borick, C., \& Rabe, B. G. (2012). Public attitudes toward climate science and climate policy in federal systems: Canada and the United State compared. Review of Policy Research, 29(3), 335-358.

Lecours, A., \& Belard, D. (2010). Federalism and fiscal policy: The politics of equalization in Canada. Publius, 40(4), 569-596.

Marshall, C. (2011). British Columbia survives 3 years and $\$ 848$ million worth of carbon taxes. New York Times, March 22.

Mohl, R. A. (2003). Ike and the interstates: Creeping toward comprehensive planning. Journal of Planning History, 2(3), 237-262.

Nordhaus, W. (2009). A question of balance: Weighing the options on global warming policies. New Haven, CT: Yale University Press.

Pagano, M. (2010). Creative designs of the patchwork quilt of municipal finance. In G. K. Ingram \& Y.-H. Hong (Eds.), Municipal revenues and land policies (pp. 116-144). Cambridge, MA: Lincoln Land Use Institute.

Rabe, B. G. (2004). Statehouse and greenhouse: The emerging politics of American climate policy. Washington, DC: Brookings Institution Press.

Rabe, B. G. (2008). States on steroids: The intergovernmental odyssey of American climate policy. Review of Policy Research, 25(2), 105-128.

Rabe, B. G. (2010). The aversion to direct cost imposition: Selecting climate policy tools in the United States. Governance: An International Journal of Policy, Administration, and Institutions, 23(4), 583-08.

Rabe, B. G. (2011). Contested federalism and American climate policy. Publius, 41(3), 494-521.

Raymond, L. (2010). The emerging revolution in emissions trading policy. In B. G. Rabe (Ed.), Greenhouse governance: Addressing climate change in America (pp. 101-125). Washington, DC: Brookings Institution Press.

Rowlands, I. (2008). Integrating climate policy and energy policy. In Steven Bernstein, Jutta Brunnée, David G. Duff, \& Andrew J. Green (Eds.), A globally integrated climate policy for Canada (pp. 293-311). Toronto, ON: University of Toronto Press.

Selin, H., \& Van Deveer, S. (Eds.). (2009). Changing climates in North American politics: Institutions, policymaking, and multilevel governance. Cambridge, MA: MIT Press.

Smart, M. (2011). The impact of sales tax reform on Ontario consumers: A first look at the evidence. University of Calgary SPP Research Papers, 4(3), 1-21.

Surowiecki, J. (2011). Pumped up? New Yorker, April 18, 49.

Watts, R. A. (2010). Gasoline taxes: An examination of news media discourse related to gas tax funding in six states. Burlington, VT: University of Vermont Transportation Research Center.

Whitford, A. (2007). Designing markets: Why competitive bidding and auctions in government often fail to deliver. Policy Studies Journal, 35(1), 61-85. 